\title{
RESPON PERTUMBUHAN DAN PRODUKSI KACANG TANAH (Arachis hypogaea L.) PADA BERBAGAI PENGGUNAAN MULSA DAN PUPUK KANDANG SAPI
}

\section{Responses of growth and production of peanuts (Arachis hypogaea L.) using various mulch and cow manure}

\author{
Asmuliani Rasyid* \\ Program Studi Agroteknologi, Fakultas Pertanian dan IImu Perikanan, Universitas Pohuwato, Pohuwato, Indonesia \\ Doi: 10.37195/jac.v1i2.68
}

*KORESPONDENSI

Telepon: +62-853-4114-7151

E-mail: asmulianirasyid@gmail.com

JEJAK PENGIRIMAN

Diterima: 10 Mei 2019

Revisi Akhir: 28 Agu 2019

Disetujui: 31 Agu 2019

KEYWORDS

Peanut plants, Mulch, Cow manure

\section{KATA KUNCI}

Tanaman kacang tanah, Mulsa, Pupuk kandang sapi

\section{ABSTRACT}

This research aimed to find the responses of growth and production of peanuts using various mulch and cow manure. This research starts from October 2017 until March 2018 in Palopo Village, Marisa District, Pohuwato Regency, Gorontalo. The experimental design used was a randomized block with factorial. The first factor was the use of various mulch which was consisted of 3 levels, such as without mulch $\left(M_{0}\right)$, silver black mulch $\left(M_{1}\right)$, and straw mulch $\left(M_{2}\right)$. The second factor was the use of cow manure which was consisted of 2 levels, such as without cow manure $\left(S_{0}\right)$ and $8 \mathrm{~kg}$ each ground bed cow manure. Each treatment was repeated 3 times. The results showed that the treatment of the use of silver black mulch showed the best result on plant height and number of leaves. The $8 \mathrm{~kg}$ of cow manure treatment showed the best result on fresh pod weight and dry pod weight. There was no interaction between the use of mulch and cow manure.

Penelitian ini bertujuan untuk mengetahui pengaruh respon pertumbuhan dan produksi kacang tanah (Arachis hypogaea L.) pada berbagai penggunaan mulsa dan pupuk kandang sapi. Penelitian ini berlangsung dari Oktober 2017 sampai Maret 2018 di Desa Palopo, Kecamatan Marisa, Kabupaten Pohuwato, Provinsi Gorontalo. Rancangan percobaan yang digunakan adalah rancangan acak kelompok dengan pola faktorial. Faktor pertama adalah penggunaan mulsa terdiri dari tiga taraf percobaan yaitu tanpa mulsa $\left(\mathrm{M}_{0}\right)$, mulsa hitam perak $\left(\mathrm{M}_{1}\right)$ dan mulsa jerami padi $\left(\mathrm{M}_{2}\right)$. Faktor kedua adalah pemberian pupuk kandang sapi yang terdiri dari dua taraf percobaan yaitu tanpa pupuk kandang sapi $\left(\mathrm{S}_{0}\right)$ dan $8 \mathrm{~kg}$ pupuk kandang sapi per bedengan $\left(\mathrm{S}_{1}\right)$. Masing-masing perlakuan diulang 4 kali. Hasil penelitian yang diperoleh adalah perlakuan penggunaan mulsa hitam perak yang memberikan hasil terbaik terhadap tinggi tanaman dan jumlah daun. Perlakuan pemberian pupuk kandang sapi $8 \mathrm{~kg}$ per bedengan memberikan hasil terbaik terhadap parameter berat polong segar dan kering. Tidak terdapat interaksi perlakuan antara penggunaan mulsa dan pemberian pupuk kandang sapi.

\section{PENDAHULUAN}

Kacang tanah merupakan tanaman kacang-kacangan utama yang menduduki urutan kedua setelah kedelai. Kacang tanah memiliki nilai ekonomis yang tinggi karena dapat digunakan sebagai bahan baku masakan dan bahan tambahan pakan ternak. Oleh karena itu komoditas ini memiliki peluang 
besar dalam negeri yang cukup tinggi sehingga berpotensi untuk dikembangkan.

Kacang tanah banyak diminati oleh masyarakat karena mengandung protein sekitar 25-30\%; lemaknya 40-50\%; karbohidrat 12\%; kalori 540 kal, vitamin A 130 SI; vitamin B1 0,86 mg; B2 0,13 mg; B3 9 mg; serat 2,3 g; abu 1,6 g; kalsium $73 \mathrm{mg}$; besi 2,4 $\mathrm{mg}$; fosfor $289 \mathrm{mg}$; air $5 \mathrm{~g}$; dan vitamin C 1,6 mg (Cahyono, 2007). Badan Litbang Penelitian (2012) menyatakan bahwa kacang tanah yang dikonsumsi dapat menyimpan energi lebih lama sehingga kadar gula darah akan naik secara perlahan sehingga merasa kenyang atau bertenaga lebih lama. Kacang tanah mengandung serat alami yang tinggi dan antioksidan sehingga mengurangi resiko penyakit kanker dan jantung juga mengandung arginin yang berperan memperkuat kekebalan tubuh.

Kabupaten Pohuwato merupakan salah satu sentra budidaya kacang tanah di Provinsi Gorontalo. Data Badan Pusat Statistik Kabupaten Pohuwato menunjukkan bahwa produksi kacang tanah tiga tahun terakhir mengalami penurunan (BPS, 2017). Peningkatan produksi kacang tanah dapat dilakukan dengan perbaikan budidaya yaitu dengan budidaya menggunakan mulsa. Penggunaan mulsa bertujuan untuk menekan pertumbuhan gulma, mencegah kehilangan air tanah, serta suhu dan kelembaban tanah agar relatif stabil. Penggunaan mulsa merupakan upaya memodifikasi kondisi lingkungan agar sesuai bagi tanaman, sehingga tanaman dapat tumbuh dengan baik. Mulsa bisa mempengaruhi suhu tanah yang dapat mempercepat fermentasi bahan organik. Penggunaan mulsa juga menekan pertumbuhan gulma (Mulyatri, 2003).

Dalam peningkatan produksi kacang tanah, upaya lain yang dapat digunakan yaitu dengan cara penggunaan pupuk kandang. Pupuk kandang adalah salah satu pupuk organik yang memiliki kandungan hara yang dapat mendukung kesuburan tanah dan pertumbuhan mikroorganisme dalam tanah. Pemberian pupuk kandang dapat menambahkan unsur hara, mendukung pertumbuhan mikroorganisme dan memperbaiki struktur tanah. Pupuk kandang memiliki sifat yang alami dan tidak merusak tanah. Pupuk kandang menyediakan unsur makro (nitrogen, fosfor, kalium, dan belerang) serta unsur mikro (besi, seng, boron, kobalt, dan molibdenum) (Mayadewi, 2007). Penelitian penggunaan mulsa dan pemberian pupuk kandang sapi diharapkan dapat memperoleh cara budidaya tanaman kacang tanah yang tepat, sehingga produksi kacang tanah dapat ditingkatkan.

\section{BAHAN DAN METODE}

\section{Bahan}

Bahan-bahan yang digunakan adalah benih kacang tanah varietas Gajah, pupuk kandang sapi, mulsa hitam perak, mulsa jerami padi dan air.

\section{Desain Penelitian}

Penelitian ini dilaksanakan dalam bentuk rancangan Faktorial Dua Faktor (F2F) dalam Rancangan Acak Kelompok (RAK). Faktor pertama adalah penggunaan mulsa terdiri dari tiga taraf percobaan yaitu tanpa mulsa $\left(\mathrm{M}_{0}\right)$, mulsa hitam perak $\left(\mathrm{M}_{1}\right)$, dan mulsa organik (jerami padi) $\left(\mathrm{M}_{2}\right)$ dan faktor kedua adalah pemberian pupuk kandang sapi yang terdiri dari dua taraf percobaan yaitu tanpa pupuk kandang sapi $\left(\mathrm{S}_{0}\right)$ dan $8 \mathrm{~kg}$ pupuk kandang sapi per bedengan $\left(S_{1}\right)$ sehingga terdapat 6 kombinasi perlakuan. Setiap perlakuan diulang sebanyak 4 kali sehingga terdapat 24 unit bedengan penelitian. Data pengamatan kemudian dianalisis menggunakan analisa varians (ANOVA). Uji lanjut menggunakan uji BNT dengan taraf $\alpha=0,05$.

\section{Persipan Lahan}

Lahan dibersihkan dari gulma dilanjutkan dengan pengolahan tanah. Pengolahan tanah dilakukan dengan menggunakan cangkul untuk menggemburkan tanah dan meratakan tanah. Selanjutnya dibuat bedengan dengan ukuran $100 \mathrm{~cm} \times 200 \mathrm{~cm}$, tinggi bedengan 50 $\mathrm{cm}$, jarak antar bedengan $50 \mathrm{~cm}$. Bedengan yang dibuat sebanyak 24 bedengan.

\section{Pemberian Pupuk Kandang Sapi}

Pupuk kandang sapi yang telah difermentasi (matang) dicampurkan ke dalam tanah masing-masing bedengan sesuai dengan perlakuan. Pupuk kandang sapi ini diberikan satu minggu sebelum tanam. 


\section{Pemeliharaan}

Pemeliharaan yang dilakukan meliputi penyulaman, penyiangan, dan penyiraman. Penyulaman dilakukan sebelum tanaman berumur 15 hari setelah tanam. Tanaman yang disulam adalah tanaman yang mati atau tumbuh abnormal. Penyiangan dilakukan jika terdapat gulma diantara tanaman kacang tanah, karena bisa mengganggu pertumbuhan tanaman. Penyiraman dilakukan dua kali sehari.

\section{Panen}

Pemanenan dilakukan pada saat tanaman berumur 95-120 hari setelah panen atau penampilan fisik tanaman menunjukkan seperti batang mulai mengeras, polong berwarna coklat kehitaman, sebagian besar daun sudah mulai menguning dan berguguran, dan bila dipegang polong terasa keras dan berisi penuh. Panen harus dilakukan secara serempak.

\section{Parameter Pengamatan}

Parameter pengamatan terdiri dari tinggi tanaman $(\mathrm{cm})$, jumlah daun (helai), berat polong segar (gram) dan berat polong kering (gram). Tinggi tanaman diukur dari pangkal batang hingga titik tumbuh tanaman. Jumlah daun dihitung jumlah tangkai daun setiap tanaman sampel. Tinggi tanaman dan jumlah daun dilakukan setiap dua minggu sekali pada umur tanaman 2 minggu setelah tanam (MST) sampai 8 MST. Berat polong segar ditimbang sesegera mungkin setelah polong kacang tanah dipisahkan dari tanaman kacang tanah yang telah dipanen. Berat polong kering ditimbang setelah polong segar sudah dikeringkan 3-5 hari di bawah terik matahari.

\section{HASIL DAN PEMBAHASAN}

\section{Pengaruh Penggunaan Mulsa terhadap Pertumbuhan dan Produksi Tanaman Kacang Tanah}

Rata-rata tinggi tanaman kacang tanah tertinggi pada tujuh MST adalah penggunaan mulsa hitam perak $\mathrm{M}_{1}(32,086 \mathrm{~cm})$ dan berbeda nyata dengan penggunaan mulsa organik $\mathrm{M}_{2}$ $(27,461 \mathrm{~cm})$ dapat dilihat pada Tabel 1. Ratarata jumlah daun kacang tanah tertinggi pada enam MST adalah penggunaan mulsa hitam perak $M_{1}$ (10,461 helai) dan berbeda nyata dengan penggunaan mulsa organik $\mathrm{M}_{2}(9,490$ helai) disajikan pada Tabel 2.

Penggunaan mulsa plastik hitam perak memberikan respon paling baik dibandingkan dengan penggunaan mulsa organik. Penggunaan mulsa plastik hitam perak dapat memantulkan cahaya matahari. Cahaya matahari yang diterima oleh tanaman dapat memperlancar proses fotosintesis. Hal ini sejalan dengan pernyataan Kusumasiwi, Muhartini, dan Trisnowati (2012) bahwa permukaan bagian atas mulsa plastik dapat memantulkan cahaya matahari, sehingga suhu di bawah tajuk tanaman meningkat, selain itu intensitas cahaya yang terserap oleh tanaman menjadi lebih besar.

Tabel 1. Hasil Uji BNT Rata-rata Tinggi Tanaman Kacang Tanah Umur 7 MST pada Perlakuan Penggunaan Mulsa

\begin{tabular}{ll}
\hline Perlakuan & Tinggi Tanaman $(\mathrm{cm})$ \\
\hline $\mathrm{M}_{1}$ & $32,086^{\mathrm{a}}$ \\
$\mathrm{M}_{0}$ & $29,336^{\mathrm{a}}$ \\
$\mathrm{M}_{2}$ & $27,461^{\mathrm{b}}$ \\
\hline BNT $_{a=0,05}$ & 3,245 \\
\hline
\end{tabular}

Ket.: Angka-angka yang diikuti dengan huruf yang tidak sama berarti berbeda nyata pada uji BNT taraf $a=0,05 ;$ MST $=$ Minggu setelah tanam

Tabel 2. Hasil Analisis Uji BNT Rata-rata Jumlah Daun Kacang Tanah pada Umur 6 MST pada Perlakuan Penggunaan Mulsa.

\begin{tabular}{ll}
\hline Perlakuan & Jumla Daun (Helai) \\
\hline$M_{1}$ & $10,461^{\mathrm{a}}$ \\
$\mathrm{M}_{0}$ & $10,163^{\mathrm{a}}$ \\
$\mathrm{M}_{2}$ & $9,490^{\mathrm{b}}$ \\
\hline BNT $_{a=0,05}$ & 0,705
\end{tabular}

Ket.: Angka-angka yang diikuti dengan huruf yang tidak sama berarti berbeda nyata pada uji BNT taraf $a=0,05 ;$ MST $=$ Minggu setelah tanam

Lebih lanjut dikemukakan oleh Prayoga, Maghfoer, dan Suryato (2016) bahwa permukaan mulsa plastik hitam perak bersifat seperti kaca yang dapat memantulkan sinar matahari, pemantulan tersebut dapat mempengaruhi proses fotosintesis bagi tanaman. Oleh karena itu fotosintat yang dihasilkan menjadi lebih besar dan berpengaruh terhadap pertumbuhan tanaman.

Selain itu warna hitam yang berada di bawah berfungsi untuk menyerap panas dan menjadikan suhu tanah lebih stabil. Menurut pendapat Kusumasiwi dkk. (2012) bahwa penggunaan mulsa plastik dapat mengurangi penguapan sehingga kebutuhan 
air bagi tanaman tercukupi. Hal ini dapat mempengaruhi perkembangan serta pertumbuhan akar tanaman.

\section{Pengaruh Pemberian Pupuk Kandang Sapi terhadap Pertumbuhan dan Produksi Tanaman Kacang Tanah}

Rata-rata berat polong segar tanaman kacang tanah yang tertinggi yaitu perlakuan $8 \mathrm{~kg}$ pupuk kandang sapi per bedengan $\mathrm{S}_{1}$ $(1.229,308 \mathrm{~g})$ dan tidak berbeda nyata. Ratarata berat polong kering tanaman kacang tanah yang tertinggi yaitu perlakuan $8 \mathrm{~kg}$ pupuk kandang sapi per bedengan $S_{1}(697,462$ gram) dan tidak berbeda nyata dapat dilihat pada Gbr. 1. Pada parameter berat polong dengan perlakuan $8 \mathrm{~kg}$ pupuk kandang sapi per bedengan memberikan hasil yang lebih baik dibandingkan dengan perlakuan tanpa pupuk kandang sapi per bedengan.

Hal ini dapat dikarenakan kebutuhan unsur hara yang dibutuhkan kacang tanah sudah tercukupi dan kondisi tanah yang lebih baik secara kimia, fisik, dan biologi sehingga ginofor dapat menembus tanah dengan baik yang dapat menjadikan jumlah polong jadi semakan meningkat. Hal ini sesuai dengan pendapat Simanjuntak (2013) bahwa keadaan fisik tanah yang baik apabila dapat menjamin pertumbuhan akar tanaman dan mampu sebagai tempat aerasi dan lengas tanah, yang semuanya berkaitan dengan peran bahan organik. Lebih lanjut dikemukakan oleh Julaeha, Kusparwanti, dan Herlinawati (2017) bahwa pemberian pupuk kandang sapi dapat memperbaiki tekstur tanah menjadi gembur dan menyebabkan sejumlah besar gonofor yang terbentuk pada cabang tersebut masuk ke dalam tanah yang kemudian berkembang menjadi polong dan biji.

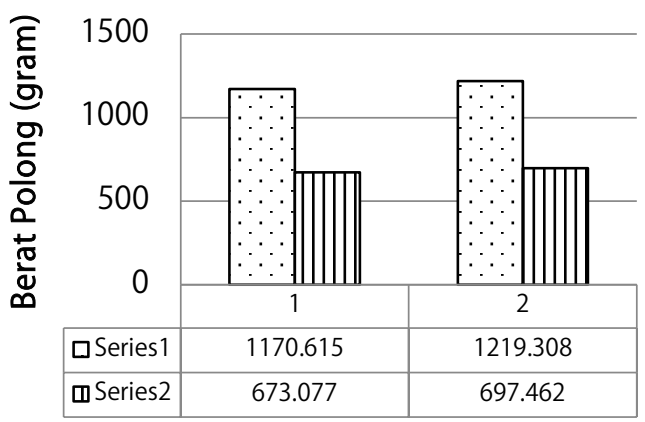

Gbr. 1. Rerata jumlah biji kacang tanah setelah aplikasi pupuk cair limbah buah dan sayur

\section{KESIMPULAN}

Perlakuan penggunaan mulsa plastik hitam perak memberikan hasil terbaik terhadap parameter pengamatan tinggi tanaman dan jumlah daun tanaman kacang tanah. Perlakuan pemberian pupuk kandang sapi $8 \mathrm{~kg}$ per bedengan memberikan hasil terbaik terhadap parameter berat polong basah dan berat polong kering. Tidak terdapat interaksi antara penggunaan mulsa dan pemberian pupuk kandang sapi terhadap pertumbuhan dan produksi kacang tanah.

\section{DAFTAR PUSTAKA}

Badan Litbang Penelitian. (2012). Kacang tanah: sumber pangan sehat dan menyehatkan. Sinar Tani. Agroinovasi. Retrieved August 18, 2017, from http://www.litbang.pertanian.go.id/downl oad/302/file/KACANG-TANAH-SUMBERPANGAN.pdf

BPS. (2017). Pohuwato dalam Angka 2017. Badan Pusat Statistik Kabupaten Pohuwato: Pohuwato.

Cahyono, B. (2007). Budidaya Kacang Tanah. Semarang: Aneka Ilmu.

Julaeha, A., Kusparwanti, T. R., \& Herlinawati. (2017). Peningkatan hasil panen melalui aplikasi berbagai pupuk kandang dan perebahan tanaman kacang tanah. Agriprima, Journal of Applied Agricultural Sciences, 1(1), 41-45.

Kusumasiwi, A. W. P., Muhartini, S., \& Trisnowati, S. (2012). Pengaruh warna mulsa plastik terhadap pertumbuhan dan hasil terung (Solanum melongena L.) tumpangsari dengan kangkung darat (Ipomea reptans Poir). Vegetalika, 1(4), 118-127.

Mayadewi, N. N. A. (2007). Pengaruh Jenis pupuk kandang dan jarak tanam terhadap pertumbuhan gulma hasil jagung manis. Agritrop, 26(4), 153-159.

Mulyatri. (2003). Peranan pengolahan tanah dan bahan organik terhadap konservasi tanah dan air. J. Ilmu Pertanian, 13(1), 6576.

Prayoga, K. M., Maghfoer, M. D., \& Suryanto, A. (2016). Kajian penggunaan mulsa plastik dan tiga generasi umbi bibit yang berbeda pada komoditas kentang (Solanum 
tuberosum L.) Varietas Granola. Jurnal Produksi Tanaman, 4(2), 137-144.

Simanjuntak, N. C., Bayu, E. S., \& Nuriadi, I. (2013). Uji efektifitas pemberian paclobutrazol terhadap keseimbangan pertumbuhan tiga varietas tanaman kacang tanah (Arachis hypogaea L.). Jurnal Online Agroekoteknologi, 2(1), 279-287. 